\title{
THE PATEMBAYAN CONCEPT TO SPATIAL CHANGES OF CANDIREJO TOURISM VILLAGE
}

\author{
SARI, Suzanna Ratih ${ }^{1 *}$; SOEWARNO, Nindyo ${ }^{1}$; NURYANTI, Windu' ${ }^{1}$; PRAMITASARI, Diananta ${ }^{1}$ \\ ${ }^{1}$ Gadjah Mada University, Faculty of Engineering, Architecture Department \\ Jalan Grafika No. 2 Campus UGM, Yogyakarta 55581, INDONESIA \\ * Corresponding author: ratihsaris@yahoo.com
}

\begin{abstract}
Candirejo village is one of villages that had been neglected in Borobudur the famous Buddhist Temple in Indonesia. Since it began to be visited by tourists, the community responded by conducting tourism village space consolidation based on patembayan concept. The process of space consolidation is involving the whole tourist village community and rural assets. The participation of the community in supporting the space consolidation of tourism village has brought a change in the shape of social value and village spatial. The concept of social organization that experienced a shift from community groups into patembayan groups has changed the way people think.
\end{abstract}

Keywords: Tourism; social change; spatial changes in tourism village.

\section{INTRODUCTION}

The Borobudur people are unique due to the historical story. As the most famous tourist attraction in Central Java, plenty of tourists are coming and visiting Borobudur temple. There are many factors forces local people to make any changes in their living. One of them is tourism factor. In the context of "patembayan" as a basic for spatial changes in tourism village, there is relationship between "patembayan" and tourism spatial changes. This interaction is dominant because both of them are giving strong influence and giving means to each other. In terms of tourism village, Candirejo people create some activities that always required space or territory. For example, they have to fulfil tourist's activities like enjoying panoramas, buying souvenirs, sightseeing, etc.

To accommodate such activities, People have to dig all the tourism potentials. However, to decide everything that tourists needs including facilities local people have to pass some discussion process.

Space or territory setting created by pottery makers had brought significant influence towards the behavior setting of pottery makers and other related users. It means that, there is relation between space as a chain of physical aspects and space as spatial aspects, so that it could be used to facilitate human activities. Behavior setting contains many aspects of people who did their activities and interact as their characters in a place or space within time frame.

The most attractive issue in this research rose since Candirejo declared as the first tourism village and become pilot project for the other rural urban area surrounding Borobudur. There are many changes had already made for fulfilling the tourists consumption. The changes made by local people mostly are attractions that concerned about the sustainability of local value such as the origin of natural scenic beauty, natural landscape of the village, local traditional culture of the people, etc. Before local people used paddy field for area of working but now they prefer to involve some tourists to do what they are usually do. To learn more detail about Candirejo tourism village therefore in this research tried to focus on what kind of tourism village spatial changes occurred in Candirejo village and how far patembayan (gesselschaft) influencing tourism spatial.

\section{METHODOLOGY}

The issue raised in this research is Space Pattern of Candirejo Tourism Village Based on Patembayan as traditional value. The method used in this research is descriptive method. By using this method, the researcher would describe in detail the spatial changes in Candirejo tourism village due to the implementation of Patembayan system in their village. Some steps done in this research were 1) village observation as a process where researcher directly involved in the field study to find out what the researcher looking for, and 2) the next step would be interview to find any information related to spatial changes and the role of patembayan (gesselschaft) into spatial changes of tourism village. Literature studies executed to elaborate the researcher's knowledge about tourism village 
and patembayan as the critical value in performing tourism spatial village. In this research, documentation needed especially to record the physical condition of the village, which then used for supporting data related to the research material. Data collected would further analyzed by researcher and used as a basic to make conclusion.

\section{DISCUSSION}

Candirejo tourism village is one of rural urban in Magelang Regency, Central Java, Indonesia. This village area is closed to Borobudur Temple the biggest Buddhist Temple in Indonesia. The location is situated around $3 \mathrm{~km}$ from Borobudur Temple. Candirejo is being promoted by local government for tourism since 1996 and has many tourists and visitors visited each year. Candirejo is also completed by many supporting facilities, such as transportation, telecommunication, medical, and accommodation facilities.

As one of rural urban, Candirejo was starting to change into modern. Before Candirejo village is an agriculture area that covered fully with green. Since Candirejo declared as a tourism village, Candirejo has already changed from traditional village into semi modern village. One of the reason is many people are tend to involve in some tourism activities; they changed their mindset by receiving tourism in their life. Response local people at that time toward tourism were preparing their village to become tourism village. Many performances of the village modernized and some were remain including traditional values.

Candirejo presently become one of the famous tourism villages that offered any kinds of tourism potentials physically as well as culturally. For examples: it is a unique and total different experience of tourism village trip in Candirejo. Tourist whole holiday trip will spent on Candirejo Village, with local housing accommodation. The accommodations in tourism village are special. Visitors can spend the nights using homes stay provided in the village. It gives visitors a memorable moment because they can feel a purely village atmosphere. This way, will allow tourist to blend in with the local family and learn their daily routines. Candirejo has over 50 homestays open to visitors and offers several tour packages including cooking classes featuring traditional cuisines and snacks.

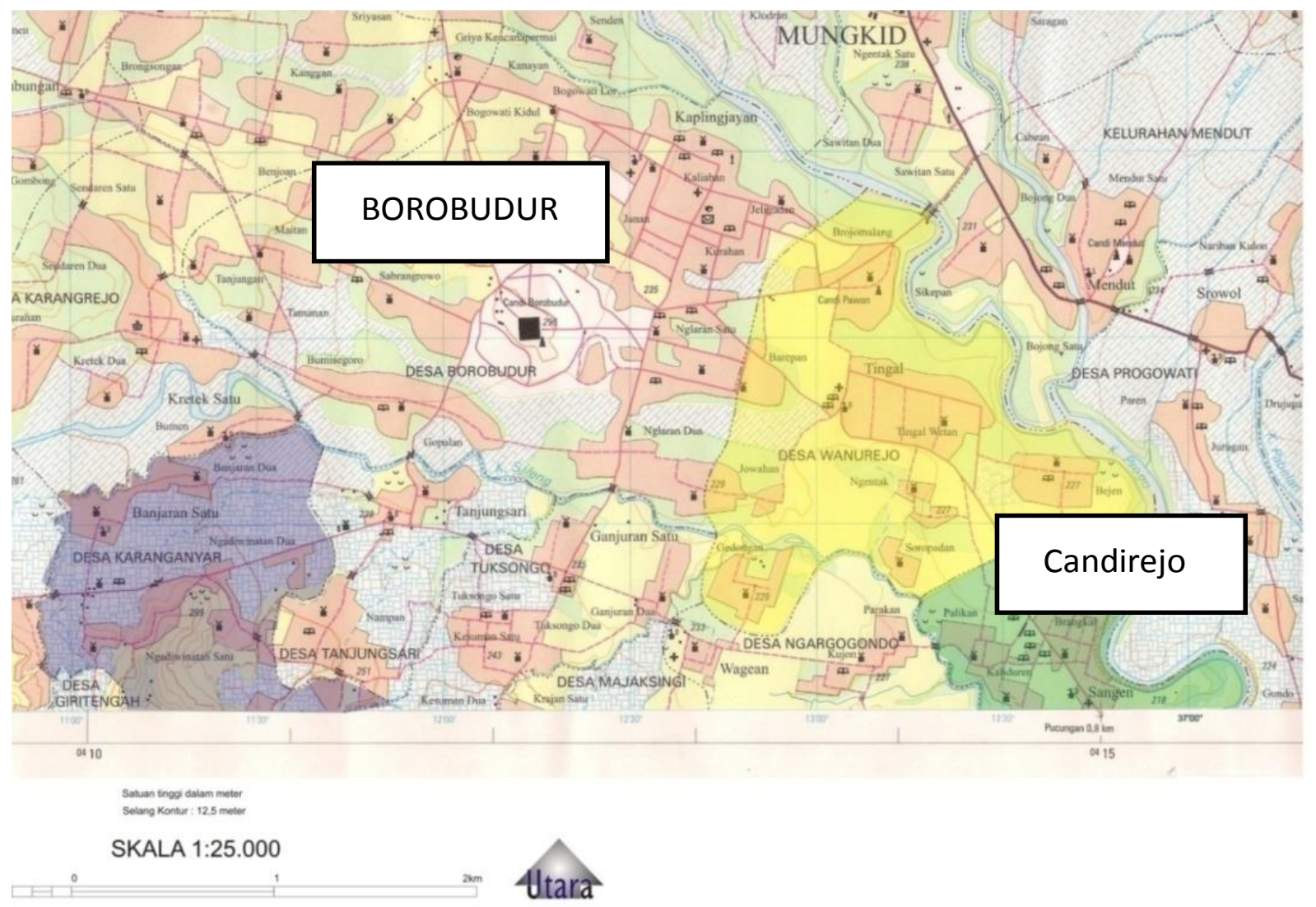

Figure 1. The Map of Candirejo Village 
Candirejo also offers various tourist attractions. Ranging from local custom attractions, local art attraction, also local home industries which sell local handicraft and souvenirs.

The popular local tradition could be enjoyed by tourist is Nyadran Ceremony. It's a prayer sending ritual addressed to their ancestors. This annual event held on Ruwah month of Javanese Calendar. Other attraction options that Candirejo provides are village tour and sightseeing. Besides watching ceremonies, there is still a choice of tours that tourist can do during a visit to Candirejo. One of them is trip around the village. Usually, tourist does this activity by using delman (local transportation) or on foot. On this occasion, tourist served to a unique tradition and local culture, arts, and handycrafts.

The masterpiece of Candirejo is Pandanus homemade crafts. In this occasion, tourists will give any attention to the process of making Pandanus mats, bags, and other products.

\section{PATEMBAYAN (GESSELSCHAFT) AS STRATEGY FOR TOURISM SPATIAL PLANNING}

Patembayan actually is a system of people organization. According to Tönnies' (2001), he named patembayan with Gesellschaft (associational society) and paguyuban with Gemeinschaft (communal society). In the rural, peasant societies that typify the Gemeinschaft, personal relationships are defined and regulated on the basis of traditional social rules. People have simple and direct face-to-face relations with each other that are determined by Wesenwille (natural will)-i.e., natural and spontaneously arising emotions and expressions of sentiment. The Gesellschaft, in contrast, is the creation of Kürwille (rational will) and typified by modern, cosmopolitan societies with their government bureaucracies and large industrial organizations. In the Gesellschaft, rational self-interest and calculating conduct act to weaken the traditional bonds of family, kinship, and religion that permeate the Gemeinschaft's structure. In the Gesellschaft, human relations are more impersonal and indirect, rationally constructed in the interest of efficiency or other economic and political considerations.

As for one of modern forces in the village, tourism has contributes to a wide range of issues of changes. For example: before tourism project implemented in Candirejo village, local community have very traditional life and most of them have spirit to keep ,guyub“ and ,gotong royong“ in every single of village activities. People made this social cohesion to be become principle of life that could tighten the relationship among them and it is not easily changed by any influences. They even preserve their cohesion to become one of the most attractive tourist attractions in their area. The local social organization existed in Candirejo with paguyuban concept is regular social gathering, "pengajian" (religious gathering). In this community organization has no clear target; what they always did is they just community gathering.

Haryadi and Setiawan (2010) in his book described the public appreciation of the environment with emphasis on perception. They told that the perception of the environment or environmental perception is the interpretation of a set by individual, based on cultural background, and experience a different reason. Every individual people, thus will have a different perception of the environment. In the case of Candirejo village is that every member of people has his own perception of tourism. Some people accepted tourism in their life and some are refuse it. However, it is also possible some groups of individuals have tendency perceptions of the same or similar environment, due to the similarity of cultural background, reason and experience. In the context of environmental anthropology studies, the issue of the perception of the environment will involve what called the emic and etic aspects. Emic describe how an environment perceived by the groups in the system (how a group of people perceives its environment). While etic or outsider is how observers perceive the same environment in its own way. (Haryadi and Setiawan, 2010).

Haryadi and Setiawan (2010) emphasized the need to understand human's behaviour or society different in every region in the use of space. This is what local leader in Candirejo did. He tried to understand his people to introduce tourism to the people, because not every group of people could accept tourism. Asking people to involve in tourism activities is a challenge for local leader. Tourism spaces in this case are seems to have meaning and value of plural and different, depending on the level of appreciation and cognition of individuals who use the space. In other words, this approach see that aspects of norms, culture, psychology different societies will generate concepts and form a different space (Rapoport, 1996). Behavioural and environmental linkages, both will affect individual response to environmental in this case is tourism village stimuli appear.

The strategy done by local leader to make the same perception about tourism in Candirejo is by using social organization (gemeinschaft/paguyuban\}. Through this group of people, local leader tried to bring his people from traditional to modern way of thinking and changed the group of people was no 
longer paguyuban but gesellshaft/patembayan. Then everything has slowly eroded by tourism activities. People are starting neglecting "guyub" in their daily life. They just chase a piece of big cake for their own never think about other people. Each people only tried to collect dollar from tourists as much as possible from tourism activities. They access tourists directly without concerning other people and sell any kind of tourism assets in Candirejo through direct selling. Furthermore, People in Candirejo are competing in providing tourism facilities such as homestays, tourist guides, travel agents, etc. The other problems also raise regarding to this matter are people has their own perception, need, mission, expectation towards tourism. This may create disharmony among the society and tourism entrepreneurs. While, poor people in Candirejo who could not access tourist directly, they do not get the fruits of tourism activities, then we must say this tourism business is only for a certain class In the light of such situations, the community may feel that tourism cannot always be the most appropriate form of improving economic condition of the people. Fortunately, unlike other tourism villages surround Borobudur temple. The local leader of Candirejo tourism village has taken promptly action to reduce this condition. He together with the society, have created tourism village coop especially to accommodate all the ideas of tourism development in their village, tourism management and try to make economic concept that could provide tourism profit to Candirejo people as a whole including the poor and not individually. To avoid social conflict, Tourism village coop as patembayan organization, tighten up the relationship among them in managing tourism facilities including spatial changes for tourism facilities and economic profit of tourism coop. The members of tourism village coop are local people with modern mindset (they could receive tourism as changes factor), local leader, NGO's, related stakeholders.

1. Local leader as cultural breaker to lead, direct and assist the communities to jointly realize tourism village program

2. Community participation in supporting tourism activities is one of the important contributions. Local Leader without community support would not be able to realize tourism village program with good wishes

3. The role of stakeholders is to support the process of consolidation of tourist village spaces

The success of tourism spatial changes in the village is very dependent on the level of people's ability to be open to partnerships with stakeholders.
These levels of public disclosures rear overshadow educational, cultural and economic conditions of people that led the community respond and manifest tourism in their lives. Technical assistance and material required by the community to support tourism activities have been able to evoke the spirit of supporting the consolidation of spatial changes to accommodate tourist activities in the village. People have become more concerned and appreciated the results of consensus done by tourism village coop in utilizing the tourism potentials so that it becomes a better tourism village, attractive and sustainable as well as having economic value for society.

All the above three factors must exist within social groups of patembayan particularly in the implementation of the consolidation process in deciding spaces for tourist facilities. Each of these factors cannot stand on their own to achieve successful development of tourism village program, but all three must be present in the whole group of patembayan people who have business and economic orientation. Tourist spaces created as a social group of patembayan products tailored to the needs of tourists and the agreement of the community is the production spaces that have high economic value.

The most appropriate application of patembayan concept in people organization in rural area that brings success is patembayan concept that was not leave "guyub" as social cohesion of society. With this concept of social groups, people can create harmony and tight the social cohesion in tourism village, so that it would provide a broader economic impact not only members of the group but also all layers of the communities.

In the tourism village coop as one of the form of patembayan social group, people usually discuss, create and make some tourism packages of local culture and natural tourism potential of the village.

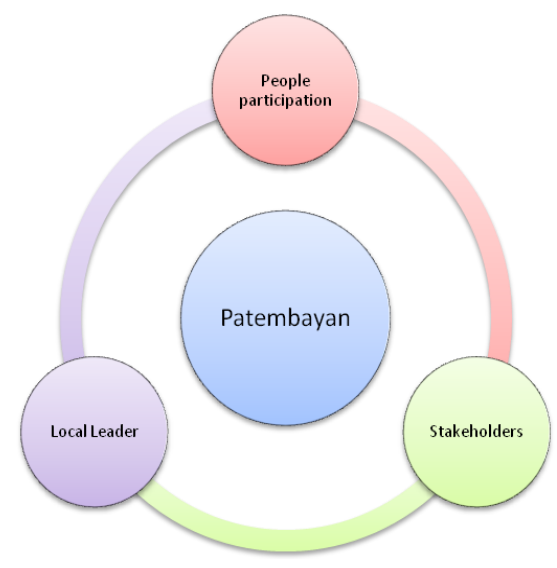

Figure 2. Persons in charge in Patembayan group of people 
Based on their discussion they select which spatial part of villages will change as tourist attraction. To support this activity, the members of coop some agreements/consensus of all the spaces used for accommodating tourist activities. Without any agreement from this patembayan group of people, village could not easily run tourism village programs.

They likewise decided to promote local handicrafts, local agriculture system, homestays and another potential of tourist attractions. It will further offered to tourists as tourism package as well as to attract foreigners to visit. They manage hand in hand with the same mission and target to increase their economic income. Therefore, they are together with local leader and stakeholders manage the tourism village industries as their own enterprises that could bring lot of fruit to all local people.

Some tourism spaces had already decided as consensus to accommodate tourist's needs are as followed:

1. R. Pasugatan : place for attraction

2. R. Jlajah Deso : walking around the village

3. R. Ziaroh: place for pilgrim

4. R. Dedhaharan : place for eating

5. R. Makryo Sesarengan : tourist involves in some local activities (working together with local people)

6. R. Makaryo : industrial place

7. R. Rembug : place for discussion

8. R. Pesawangan : place for sightseeing

9. R. Parkir : parking lots

10. R. Homestay: local accommodation

11. R. Jagongan : place for sitting, talking, relaxing

Those spaces created base on tourist activities such as: sightseeing, eating, parking, sitting, discussing, enjoying cultural attraction, staying, working together, etc.

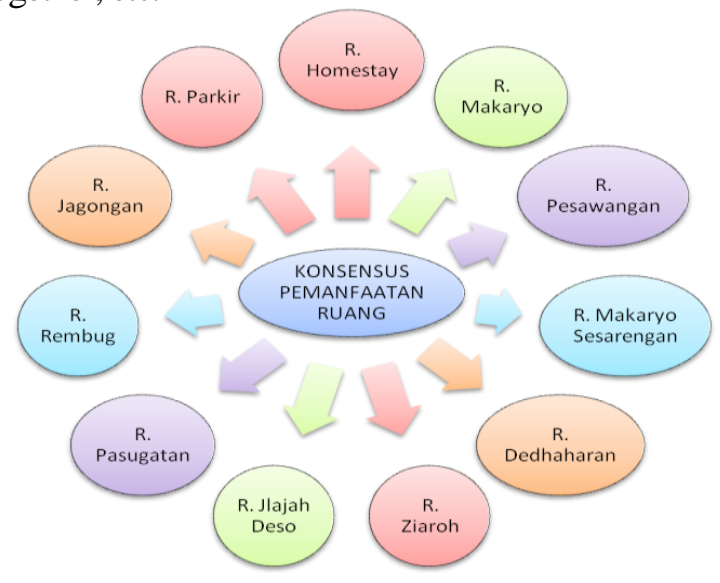

Figure 3. The village spatial uses based on Patembayan consensus
The process of spatial consolidation itself is happened from 4 (four) spatial changes:

1. Spatial commercialization : any kinds of spaces inside the traditional house that were designed for tourism purposes (used for homestay)

2. Spatial reused: the existing of open space is reused for open theatre, the existing of street is reused for parking lots, play ground also reused for parking lots, etc

3. Desecration: cemetery from village leaders as of the most secretion place are used for tourist attraction, "senthong tengah" inside the Javanese traditional house usually use as traditional sacred room which is very private is now used for welcoming tourist room. The same case with river and mountain, in the past, traditional people believed that river and mountain have sacred value. No one would not visit river or mountain individually, because they were afraid something bad will happened. But since the village was decided to become tourist destination, these two places, river and mountain are made as tourist attraction.

4. Restructure: in the past, kitchen is a dirty place and not for welcoming guest, but recently it was decided for tourist cooking lesson.

The above spatial change processes are actually one of the result of spatial consolidation done by patembayan group of people known as Candirejo Tourism Village Coop. Without consolidation, local people could not easily use every single area for tourism purpose, because some village areas are belong to local people. By involving community on tourism village coop, people could optimally give their contribution for supporting tourism village activities.

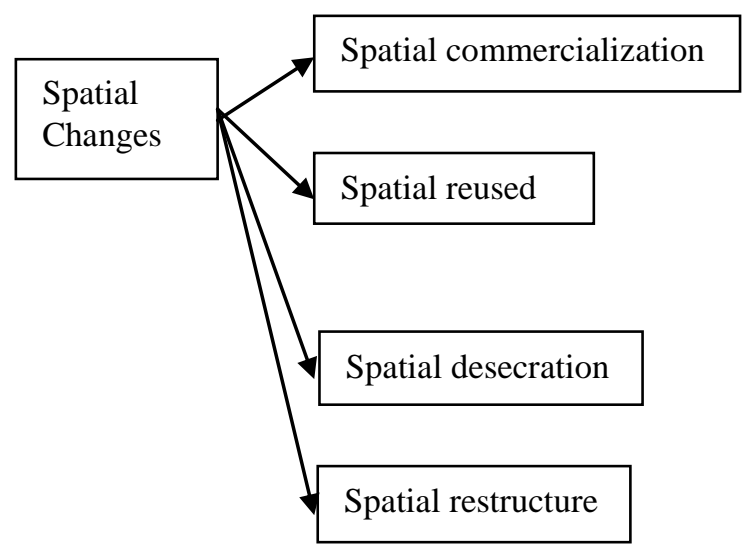

Figure 4. Spatial Change Processes 
Based on interviews with former village leader who broke traditional mindset of local people into modern mindset, there was an effect on spatial use of Candirejo tourism village. Some Candirejo's areas that changed as tourism facilities that was formed through the 4 (four) spatial changes process, i.e. agricultural land of some Candirejo communities turn into homestays, hotels, restaurants, open stage, tourist traditional market and even tourist information centre. There are also land used as a parking lot and souvenir stalls. In addition, another Candirejo tourism village land that change for tourism activities, such as:

1. The existence of streams and rivers Progo and Sileng which serves as a source of water for most residents Candirejo village for watering paddy fields, now the river is also used as a place for bathing and washing as well as a place for social interaction and communication or information exchange between residents and tourists .

2. The existence of the river Progo and Elo Sileng used for undertaking Suronan tradition: many people/visitors take advantage of the confluence of three rivers as a place for meditation and rafting

3. The beauty of Menoreh hill which is part of Candirejo village natural tourism potentials have provided many benefits for tourists.

4. The existence of the village's main road network linking the area of Candirejo village and Borobudur Temple before has very bad condition. With the influx of tourists slowly has brought changes to the physical condition of the village ( Winarni, 2006).

The following is the mapping of the utilization of Candirejo Tourism Village for Tourism activities.

\section{CONCLUSION}

The existence of patembayan social groups serve as a basic of tourism spatial setting in Candirejo tourism village. This kind of social group was formed by people who have a modern perspective in mana-

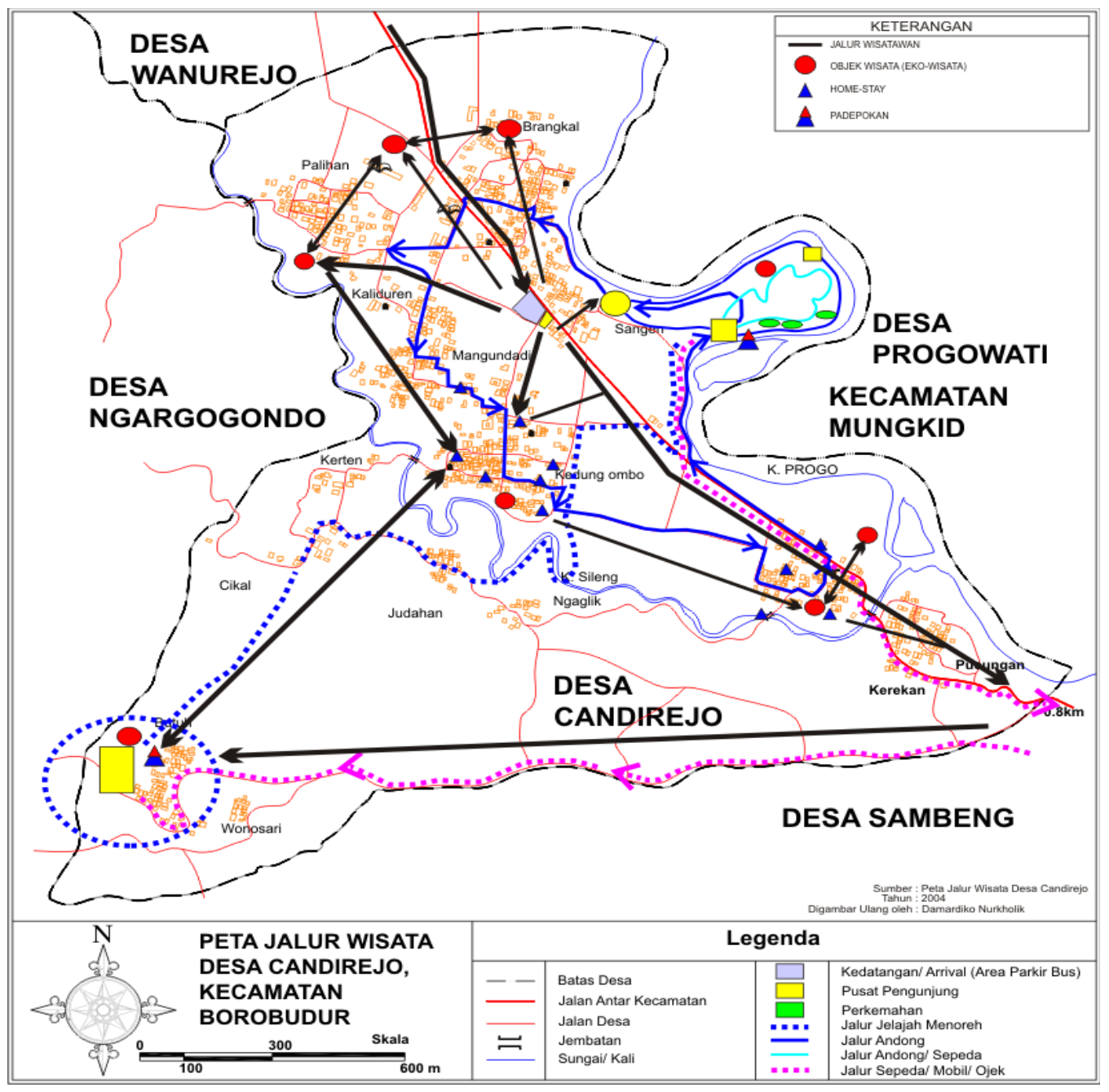

Figure 5. Map of Candirejo Village Utilization for Tourism Activities 
ging the consolidation of tourism village space. There was a process of changing from community groups (paguyuban/gemeinscaft) that get together to a social group that did not just get together and stay in touch but have a common goal (patembayan/gesselscaft). As an embodiment, as happened in the tourist village Candirejo appear tourism village coop. The output of Candirejo tourism village coop as patembayan social group of people a: physical and social changes of the village. Physical change created tourism spaces as a response toward tourist activities. There were 4 processes have already led the performing of tourism spaces: 1. Spatial reused, 2. Desecration 3. Restructure, 4. Spatial commercialization

\section{ACKNOWLEDGMENT}

I would like to thank all candirejo people who have already assisted me in doing my research. My special thank dedicated to my supervisors and all my colleges from borobudur conservation department.

\section{REFERENCES}

Tönnies, F. (Ed. Jose Harris). (2001). Community and Civil Society, Cambridge University Press (2001). Hardcover, 266 Pages, ISBN 0-52156119-1; Trade Paperback, Cambridge University Press (2001), 266 Pages, Isbn 0-521-567823

Haryadi \& Setiawan, B. (1995). Arsitektur Lingkungan Dan Perilaku (Teori, Metodologi, Dan Aplikasi), Proyek Pengembangan Pusat Studi Lingkungan Direktorat Jendral Pendidikan Tinggi Departemen Pendidikan Dan Kebudayaan, Republik Indonesia.

Rapoport, A. (1996). The Use And Design Of Open Spaces In Urban Neighborhoods, Di D. Frick (Eds) The Quality Of Urban Life, Walter De Gruiter And Co, Berlin.

Winarni. (2006). Kajian Perubahan Ruang Kawasan World Cultural Heriaget, Candi Borobudur, Sekolah Pasca Sarjana Universitas Gadjah Mada, Yogyakarta. 